\title{
Financial Technology Disruption in Indonesian Banking: From Loan and Interest Rate Perspectives
}

\author{
Hizkia H. D. Tasik ${ }^{1}$, Daniel D. Rumani ${ }^{2}$ \\ \{hizkiatasik1@gmail.com¹, daniel68pnb45@gmail.com² \\ Sam Ratulangi University, Manado, Indonesia ${ }^{1}$ \\ Aviation Polytechnic of Indonesia, Manado, Indonesia ${ }^{2}$
}

\begin{abstract}
The presence of Fintech has contributed to the changes in many industries in Indonesia. Among others, banking industry has been one of the most resilient to alterations and skeptical to disruption by Fintech. Using the data of banking industry covering national banks, regional banks, national private banks and foreign banks, from 2009 to 2019, this study aims to examine the impact of interest rate in pre-Fintech period compared to the impact in post-Fintech period. This study sets 2016 as the time threshold. Using panel data regression model, the findings suggest that the power of interest rate in changing the level of loans is lower in the postFintech than in the pre-Fintech. Additionally, in many cases, the power is even statistically insignificant in the post-Fintech. Reforms in banking loan regulation is necessary to respond to the presence of Fintech.
\end{abstract}

JEL Classification: B26, E44, G21, O14.

Keywords:

Fintech, Loan, Interest Rate, Banking Industry and Panel Data.

Article Received: 18 October 2020, Revised: 3 November 2020, Accepted: 24 December 2020

\section{Introduction}

Global economy has shown an increase in Financial Technology, so-called Fintech investment. According to KPMG's 2018 report Fintech, the total investment in Fintech in 2013 was USD 18.9 billion. The investment increased to USD 111.8 billion in 2018. Like in most countries in the world, Indonesia has experienced a vast-growing in Fintech. Likewise, the transaction value of Fintech experienced an increase. It was USD 18.64 billion in 2017 and increased 19.85 percent to USD 22.34 in 2018. From investment perspectives, the value has reached USD 176.75 million in 2017 which led to enormous market shares of Fintech in payment sector and loans with values of 38 percent and 31 percent respectively. ${ }^{1}$ Comparing it to the Fintech growth of 7 percent in the $2006-2007$ period, the growth in 2015 - 2016 has reached 78 percent which is 11 times as big with total Fintech players reaching around 140 players. The rocketing growth in 2016 indicates a significant rise of

\footnotetext{
${ }^{1}$ Data was taken from Katadata.co.id
}

Fintech. Among all Fintech players, 43 percent are engaged in payment sector, 17 percent in loan sector, 13 percent in aggregator, 8 percent in crowdfunding, 8 percent in personal finance planning, and 11 percent in any other sectors. By December 2017, the total players engaging in any Fintech businesses reached 235 companies.

From loan distribution perspectives, Fintech has also created a new episode in lending. The distribution of loan funds from Fintech in 2017 reached 2.56 trillion rupiahs with an average loan disbursement of 65.81 million rupiahs per Fintech Lending and the lowest average loan of 17.76 million rupiahs. Shockingly, the distribution has dramatically increased around 784 percent in 2018, accumulating 22.67 trillion rupiahs. On the other hand, the conventional banking services has slowed down in the past decade. In 2011, the loan distribution grew at 25.5 percent, while deposits grew at 20 percent. From December 2015 to September 2016, the loan grew at 3.7 percent and deposits at 4.34 percent. Finally, from September 2016 to September 2017, the loan only grew at 7.86 percent which totaled 4,543.38 trillion 
rupiahs. Meanwhile, the Jakarta Interbank Offered Rate (JIBOR) has decreasingly fluctuated from 2011 to 2019. In December 2012, the rate was 7.3 percent and went down to 5.3 percent in December 2013. In December 2015 and 2016, the rate was 8.1 percent which then started to decline until level of 5.8 percent in December 2019. The decline of the rate was no longer associated with the increase of loan distribution as mainstream theory predicted which was shown by the data of the loan distribution and the rate growth from 2012 to 2017 above. Shortly speaking, Fintech has significantly grown since 2016 while the decline in the loan rate seems to have ineffective power in boosting the loan distribution.

The facts have provided evidence that the Indonesian market has positively responded on the presence of Fintech, especially in lending sector. The response of the market in Fintech gets bigger from time to time and even so much bigger than that in conventional banking services. There are two implications behind these facts. Firstly, people become more convenient in using Fintech service. Secondly, conventional banking industry has a big threat and is challenged to improved. Slow response of the banking industry will lead to the end of conventional banking industry. Behind the vast-growing of Fintech, convenience in doing transaction is one of the services that Fintech has to offer. People become more convenient in making payment, accessing lending, and many more. The easy access that Fintech provides is one of the compelling reasons why people prefer to use Fintech services to the conventional banking services. For example, even though the interest rate of the loan is relatively higher than that in the conventional banks, but many people prefer ease of accessing loan to the loan with low interest rate. This example may raise a problem. Is interest rate still a valid price of the loan? Simply speaking, is interest rate still the determinant of the value of borrowing people want to have?

This study will investigate whether the interest rate still has the same power in the presence of Fintech compared to in the absence of Fintech. The result of the investigation is expected to benefit the conventional banking industry in setting the interest rate to survive in the competition of financial services and in maintaining the financial performance of the banks. The rest of this study is as follows. The next section will discuss the literature review, followed by methodologies and results, then concluded by discussion, conclusion and policy implications.

\section{Literature Review}

Regardless the vast changing in technology and business systems, the financial services sector has made a historical record to stay in status quo and be resilient to changes. Fichman et al. (2014) proved this situation and argued that banking is doubtful to disruption by technology [1]. This situation explains why there is not so much innovation among the banks either because of their stable market position or the complexity of government regulations [2].

Lee and Shin (2018) mentioned that financial markets around the globe were intensely affected by the 1990s-internet revolution. One major effect was that it lowered the costs for financial transactions. Changes in technology driven by the internet revolution reshaped the financial services industry and led to the creation of electronic finance (e-finance). The advances have motivated the rise of Fintech companies [3]. Buchak et al (2018) implicitly pointed out the similarities in role of Fintech companies and the shadow banks [4]. Jagtiani and John (2018) added that Fintech lenders have participated in the shadow banking sector and offered similar banking and other financial services - providing convenience and faster services than traditional firms without being subject to the same regulations that traditional firms are subject to [5]. Hill (2018a) agreed that some financial services are now under federal regulation and within the coverage of conventional banking. However, more sophisticated regulation of financial products as well as financial markets has become the major contributor to their development. The products and services offered outside of the conventional 
banking framework are termed shadow banking and many Fintech services fall into this category [6].

This type of banks that are non-depository institutions and inconsiderate about the traditional banking regulation has risen as a result of a dramatic change in finance market [4]. Unlike traditional lenders, Fintech lenders use big data, alternative data, and complex AI/ML algorithms to make credit decisions at no time. That said, Fintech has a potential to disrupt and to create new types of risk [5].

Buchak et al (2018) found that, using difference in difference test, traditional banks contracted in markets experienced many regulatory constraints, while at the same time, the shadow banks partially become the solutions [4]. Casanova, Cornelius and Dutta (2018) pointed out that one of the constraints was credit access. They argued that although the credit access of companies has shown improvement as the country's economy improves, entrepreneurs in emerging economies tend to continue profoundly dependent on internal sources of finance. Loan-toGDP ratios of these econonies is lower than in advanced economies, with the notable exception of China. 200 million micro-, small-, and medium sized enterprises (MSMEs) are still unserved or underserved by banks [7]. Although the businesses have the ability to borrow from banks, there are many other factors that may restrict their access to credit. For example, in both emerging and advanced countries, new firms are almost twice as likely as older firms to use the owner's personal assets as collateral [8]. Additionally, the collateral required in emerging economies is frequently twice or three times as much as in advanced economies, which particularly affecting young entrepreneurial firms.

Jagtiani and Lemieux (2018) agreed that Fintech played a role in shaping financial and banking relationships. They used the accountlevel data from Lending Club and Y-14M reported by US banks, particularly, with assets over $\$ 50$ billion and found that Lending Club's consumer lending penetrated both highly concentrated and relatively underserved banking markets. Lending Club's loans also increased in areas where the local economy was not preforming well [9].

Buchak et al (2018) argued that compared to other shadow banks, Fintech lenders serve more creditworthy borrowers and are more active in the refinancing market. Fintech lenders usually charge a premium of 14-16 basis points. They offer convenience rather than cost savings to borrowers [4].

There are five elements of the Fintech ecosystem. Firstly, Fintech startups which include payment, wealth management, lending, crowdfunding, capital market, and insurance Fintech companies; secondly, technology developers that cover big data analytics, cloud computing, cryptocurrency, and social media developers; government that includes financial regulators and legislature; financial customers including individuals and organizations; and traditional financial institutions, for example, traditional banks, insurance companies, stock brokerage firms, and venture capitalists. The technological developments such developments in infrastructure, big data, data analytics, and mobile devices help Fintech startups disintermediate traditional financial firms with unique and personalized services.

Fintech requires more than what is required by conventional business which makes this a reason why conventional business find it difficult to engage in Fintech businesses. Nakashima (2018) argued that several businesses find it challenging to progress through advanced concepts, because capability constraints. Therefore, it is necessary to design new business models and services that surpass vested interests and fulfil the demands of the society. Products and services relying on technology have been in demand through many years, and possibly, they can threaten the existing businesses; this situation clearly exhibits that such products and services are indispensable for social creation [10].

Fintech introduces a new model in which information technology is driving innovation in the financial industry. Fintech is publicized as a 
game changing, and disruptive innovation capable of trembling the traditional financial markets [3]. The presence of new technologies provides consequences that may benefit or harm the companies. One of which is called technology disruption. Lending is the primary activity of banks' operations and is also one of the banking products most susceptible to disruption. Loans are important for both lenders and borrowers. Loans are also important from a monetary policy point of view. Among others, ten purposes of loans include short-term loans, business lines of credit, equipment financing, inventory financing, merchant cash advances, business credit cards, accounts receivable financing (factoring), construction financing, real estate, and syndicated loans [11]. The forms of loans have evolved overtime and become attractive for non-bank companies which later become Fintech companies. Hill (2018b) argued that loans were the most successful products for Fintech companies which later created new alternatives in lending including lending platforms. The platforms had originated from several different perspectives: Peer-to-Peer lending, Peer-toCommercial lending, and others, collectively termed "marketplace lending". The role of these sites may be similar to the banks but the operations are somewhat different from the banks. On each of these sites, borrowers and lenders are matched directly without a bank acting as an intermediary. These lending sites also have a lighter regulatory burden than do the banks. While traditional lenders lean heavily on FICO scores, many of these alternative lenders use proprietary credit analysis which they believe gives them an edge in credit evaluation. As compared to bank lending, market place lenders have features like online application process, fast response, higher approval rates, enhanced credit analysis, and superior customer experience, lower rates than credit cards, payday lenders, online tools, lighter regulatory burden, low overhead, and entrepreneurial culture [11].

\section{$3 \quad$ Methodology and Results}

The data used in this study are taken from the statistics of several types of banks reported by Bank Indonesia. The types include national banks, regional banks, national private banks and foreign banks. The data cover total loan, production loan, consumption loan, agriculture loan, mining loan, industry loan, electricity loan, construction loan, trade loan, transportation loan, finance loan, working capital interest rate, investment interest rate and consumption interest rate from 2009 to 2019. The interest rate variables are named after the purpose of the loans. For example, working capital interest rate is the interest rate of production loan. Table 1 presents the summary statistics.

Conventionally, interest rate, $r$, is the only determinant of level of investment, $l$. Mathematically, it is defined as $I=I(r)$. This study employs basic Solow growth model to determine the impact of interest rate and technological change on the investment while assuming that the investment is made of loans from the bank. Suppose that the conventional Cobb-Douglas production function, $Y$ consists of capital, $I$ and labor, $L$ and can be written as follows, $\quad Y=F(K, L)$. With technological progress $E$, one may rewrite the function as $Y=F(K, L E)$, where $L E=L * E$ is the number of effective workers. Assuming that $y=Y / L E$ is the output per effective worker, $k=K / L E$ is the capital per effective worker, $y=f(k)$ is the production function per effective worker, and $s y=s f(k)$ is saving and investment per effective worker.

Table 1. Summary Statistics

\begin{tabular}{lcrrrr}
\hline \multicolumn{1}{c}{ Variable } & Obs & \multicolumn{1}{c}{ Mean } & Std. Dev. & \multicolumn{1}{c}{ Min } & \multicolumn{1}{c}{ Max } \\
\hline Year & 44 & 2014 & 3.20 & 2009 & 2019 \\
Bank id & 44 & 2.50 & 1.13 & 1 & 4
\end{tabular}




\begin{tabular}{lrrrrr} 
Total loan & 44 & 681669.80 & 609001.40 & 81249.00 & 1943797.00 \\
Production loan & 44 & 452018.00 & 446993.70 & 29571.00 & 1440239.00 \\
Consumption loan & 44 & 229601.40 & 175111.60 & 27585.00 & 646707.40 \\
Agriculture loan & 44 & 42209.24 & 52201.17 & 1766.98 & 198225.50 \\
Mining loan & 44 & 5590.37 & 5513.97 & 201.00 & 15376.00 \\
Industry loan & 44 & 91485.34 & 86742.33 & 823.00 & 316801.20 \\
Electricity loan & 44 & 15053.13 & 19692.85 & 18.78 & 73194.39 \\
$\begin{array}{l}\text { Construction loan } \\
\text { Trade loan }\end{array}$ & 44 & 35300.11 & 39719.56 & 682.57 & 138598.00 \\
$\begin{array}{l}\text { Transportation loan } \\
\text { Finance loan }\end{array}$ & 44 & 151833.70 & 157590.20 & 7243.00 & 464328.00 \\
$\begin{array}{l}\text { Working capital } \\
\text { interest rate }\end{array}$ & 44 & 54935.02 & 63011.71 & 2178.81 & 240981.00 \\
$\begin{array}{l}\text { Investment interest } \\
\text { rate }\end{array}$ & 44 & 11.86 & 1.87 & 7.71 & 15.69 \\
$\begin{array}{l}\text { Consumption interest } \\
\text { rate }\end{array}$ & 44 & 11.54 & 1.36 & 8.58 & 14.52 \\
\hline A & & 17.25 & 7.32 & 11.12 & 35.24 \\
\hline
\end{tabular}

Source: Author's calculation

Assuming that there is no technological progress and that the national income $y$ identity is composed by consumption, $c$ and investment $i$, the identity is then given by $y=c+i$ in a closed economy. Therefore, one may have $i=y-c$. It is assumed that one consumes from the difference between income and total saving sy, mathematically, $\quad c=(1-s) y$. Therefore, $y-c=y-(1-s) y=s y$. After doing some algebra, one may have $i=s y$. Since $s y=s f(k)$, then $i=s f(k)$ which means that the total money invested is taken out from the total money saved at a specific saving rate $s$. According to Solow model, this implies that an increase in the saving ratio will raise the total production output, but not its rate of growth. Another implication is that because the increased investment eventually increases the depreciation, the capital per worker levels off. Therefore, at a given level of technology, saving and capital accumulation cannot explain long-run economic expansion. Thus, saving rate does not efficiently alter the level of loan due to the fact that having more loans do not lead to economy expansion.

To explain the introduction of technological change, firstly, one needs to suppose that the capital accumulation, $\Delta k$ is calculated as $\Delta k=i-$ $d k$, where $d k$ is total depreciation of capital which is also the amount of investment necessary to keep the capital, $k$ constant, so-called breakeven investment. Now, suppose that technology $g$, has stepped in and the population grows at rate $n$, the break-even investment is given by $\Delta k=i-$ $(d+n+g) k$. When there is no change in capital then $i=(d+n+g) k$. Since investment is determined by interest rate then one may rewrite $i(r)=(d+n+g) k$. Therefore, it is easy to see that not only the interest rate determines the investment level but also three parameters of capital: depreciation rate, population growth rate and technological progress rate also determine the investment level. Negative $g$ is associated with the decline of $i(r)$ at any level of investment and vice versa which makes the power of interest rate weak. Also, one may simplify total saving $s f(k)$ as $v$. Now, because total also depends on the interest rate, one may have $v=v(r)$. Because $i(r)=v(r)$ then if $i(r)=(d+n+g) k$, $v(r)=(d+n+g) k$ which implies that $(d+$ $n+g) k$ also depends on interest rate $r$. In this case, because capital accumulation is calculated as $\Delta k=i(r)-d k$, therefore capital also is a 
function of interest rate $r$. Thus, one may have $i(r)=(d+n+g) k(r)$. Now, it is clear to see that although interest rate may alter the level of investment, technological change as well as depreciation rate $d$ and population growth rate $n$ also can change the investment level $i(r)$. Finally, it is assumed that one makes investment from the banks' loan which are supplied by the people in terms of saving. Therefore, total investment equals total loans and changes in investment imply changes in loans.

To test the hypothesis that the power of interest rate is weak in altering the level of investment in the presence of technology, this study uses two strategies. Firstly, the data are divided into two groups of periods, pre-Fintech era covering 2009 2016 period and post-Fintech era covering 2017 2019 period. Post-Fintech era was marked in 2017 because of the huge changes in Indonesian financial services and markets happened in 2017. Secondly, to investigate the difference in effects between the two periods, this study uses panel data regression model of loan which is given by

$$
\operatorname{loan}_{i t}=\alpha+
$$

$$
x_{i t}^{\prime} \beta+q_{i t}^{\prime} \gamma+u_{i t}
$$

where $\operatorname{loan}_{i t}$ is the predicted variable, $x_{i t}^{\prime}$ it is a $K$-dimensional row vector of interest rate variable (i.e. time-variant endogenous variables) and $q_{i t}^{\prime}$ is an $M$-dimensional row vector of control variables (i.e. time-variant explanatory variables excluding the constant), $\alpha$ is the intercept, $\beta$ is a $K$ dimensional column vector of parameters, $\gamma$ is an $M$-dimensional column vector of parameters, and $u_{i t}$ is an idiosyncratic error term.
To start the investigation on the effect of interest rate in the presence of Fintech, this study explores the effect of the interest rate before the dramatic change in Fintech and then after the change. The time threshold chosen in this study is 2016. Therefore, the pre-Fintech is the period before 2016 and the post-Fintech period is from 2016 and on. Table 2 presents the results of every regression undertaken in this study. There are nine specifications used in this study. The first is to predict the loans in general terms in 2009 - 2019 period. The second and the third are to predict the loans in general terms in 2009 - 2015 and 2016 2019 periods consecutively. The fourth and fifth are predict the production loans in $2009-2015$ and 2016 - 2019 periods consecutively. The sixth and the seventh are to predict the consumption loans in 2009 - 2015 and 2016 - 2019 periods consecutively.

The findings in table 2 suggest that the interest rates of all types of loan (working capital, investment, and construction) is significantly affecting the loans in general terms for the whole period (specification 1). However, when the periods are split into two periods, 2009 - 2015 period and 2016 - 2019 period, the power of interest rates changes substantially. Most of interest rate variables become insignificant in the second period. Surprisingly, the changes of interest rate for investment does not significantly alter the changes of construction loans in both periods (specifications 6 and 7). Meanwhile, construction interest rates are significant in all specifications but specification 5 (production loan in the second period).

\begin{tabular}{|c|c|c|c|c|c|c|c|}
\hline \multirow{3}{*}{ VARIABLES } & (1) & (2) & (3) & (4) & (5) & (6) & (7) \\
\hline & Loan & Loan & Loan & Prod. Loan & Prod. Loan & Con. Loan & Con. Loan \\
\hline & 2009-2017 & 2009-2015 & 2016-2019 & 2009-2015 & 2016-2019 & 2009-2015 & 2016-2019 \\
\hline \multirow{2}{*}{$\begin{array}{l}\text { Working Cap. } \\
\text { Interest Rate }\end{array}$} & $-343,319.7 * * *$ & $-233,596.9 * *$ & $-104,337.2$ & $-185,050.0 * *$ & $-94,758.9$ & $-48,575.6^{*}$ & $-9,582.6$ \\
\hline & $(129,188.9)$ & $(105,761.4)$ & $(609,187.1)$ & $(80,907.0)$ & $(505,194.3)$ & $(26,467.6)$ & $(117,750.9)$ \\
\hline Investment & $275,782.4^{*}$ & $210,380.5^{*}$ & $-100,390.3$ & $168,336.8^{*}$ & $-60,786.0$ & $41,998.5$ & $-39,594.6$ \\
\hline
\end{tabular}

Table 2. The Loan, Production Loan and Consumption Loan Models 


\begin{tabular}{|c|c|c|c|c|c|c|c|}
\hline & $(156,071.4)$ & $(119,169.0)$ & $(757,371.9)$ & $(91,163.7)$ & $(628,082.8)$ & $(29,823.0)$ & $(146,393.8)$ \\
\hline Construction & $-80,807.3 * * *$ & $-54,612.0^{* * * *}$ & $-102,103.3 * *$ & $-38,468.5^{* * *}$ & $-69,363.2$ & $-16,144.2^{* * *}$ & $-32,740.2 * * *$ \\
\hline \multicolumn{8}{|l|}{ Interest Rate } \\
\hline & $(14,975.5)$ & $(13,467.4)$ & $(50,967.4)$ & $(10,302.5)$ & $(42,266.9)$ & $(3,370.3)$ & $(9,851.6)$ \\
\hline Constant & $\begin{array}{c}2,965,553.7 * * * \\
(663,532.8)\end{array}$ & $\begin{array}{c}1,858,125.7 * * * \\
(650,823.4)\end{array}$ & $\begin{array}{c}4,859,408.3 * * \\
(2,301,454.2)\end{array}$ & $\begin{array}{c}1,296,496.9 * * * \\
(497,876.8)\end{array}$ & $\begin{array}{c}3,473,869.8^{*} \\
(1,908,578.8)\end{array}$ & $\begin{array}{c}562,458.3^{* * * *} \\
(162,873.6)\end{array}$ & $\begin{array}{c}1,385,484.2 * * * \\
(444,852.2)\end{array}$ \\
\hline Observations & 44 & 28 & 16 & 28 & 16 & 28 & 16 \\
\hline $\begin{array}{l}\text { Number of } \\
\text { bank ID }\end{array}$ & 4 & 4 & 4 & 4 & 4 & 4 & 4 \\
\hline
\end{tabular}

Standard errors in parentheses

$* * * \mathrm{p}<0.01, * * \mathrm{p}<0.05, * \mathrm{p}<0.1$

Source: Authors' calculation

Next, this study tries to investigate the impact of interest rate on loan distributed for specific sector of economy. The sectors discussed in this study are agriculture loan, mining loan, industry loan, electricity loan, construction loan, trade loan, transportation loan, and finance loan. The regression result predicting loan in each sector is consecutively presented in the specifications in table 3 and 4. Like in table 2, most interest variables are not statistically significant in the second period. It is interesting that working capital interest rate is insignificantly affecting agriculture loan in both periods (specifications 1 and 2) as well as electricity loans in both periods (specifications 7 and 8). Similar patterns are also found in the effect of construction interest rate.

Table 3. The Loan Models for Agriculture, Mining, Industry, and Electricity

\begin{tabular}{|c|c|c|c|c|c|c|c|c|}
\hline VARIABLES & $\begin{array}{c}\text { (1) } \\
\text { Agri. Loan } \\
\text { 2009-2015 }\end{array}$ & $\begin{array}{c}\text { (2) } \\
\text { Agri. Loan } \\
\text { 2016-2019 }\end{array}$ & $\begin{array}{c}(3) \\
\text { Mine Loan } \\
\text { 2009-2015 }\end{array}$ & $\begin{array}{c}(4) \\
\text { Mine Loan } \\
\text { 2016-2019 }\end{array}$ & $\begin{array}{c}(5) \\
\text { Industry } \\
\text { Loan } \\
\text { 2009-2015 }\end{array}$ & $\begin{array}{c}(6) \\
\text { Industry } \\
\text { Loan } \\
\text { 2016-2019 }\end{array}$ & $\begin{array}{c}(7) \\
\text { Electric Loan } \\
2009-2015\end{array}$ & $\begin{array}{c}\text { (8) } \\
\text { Electric Loan } \\
2016-2019\end{array}$ \\
\hline $\begin{array}{l}\text { Working Cap. } \\
\text { Interest Rate }\end{array}$ & $4,691.1$ & $49,058.5$ & $-3,488.3 * * *$ & -800.0 & $-37,630.4 * *$ & $-33,543.7$ & -361.7 & $15,995.3$ \\
\hline & $(8,420.8)$ & $(56,699.4)$ & $(1,276.9)$ & $(5,910.3)$ & $(17,165.9)$ & $(111,689.0)$ & $(2,989.5)$ & $(20,941.4)$ \\
\hline $\begin{array}{l}\text { Investment } \\
\text { Interest Rate }\end{array}$ & $-12,785.7$ & $-95,398.7$ & $3,168.0 * *$ & 17.3 & $33,389.8^{*}$ & $17,215.0$ & $-2,469.0$ & $-33,002.7$ \\
\hline $\begin{array}{l}\text { Construction } \\
\text { Interest Rate }\end{array}$ & $\begin{array}{l}(9,488.3) \\
-1,862.8 *\end{array}$ & $\begin{array}{c}(70,491.6) \\
-5,056.3\end{array}$ & $\begin{array}{c}(1,438.8) \\
-685.6 * * *\end{array}$ & $\begin{array}{c}(7,348.0) \\
-623.7\end{array}$ & $\begin{array}{c}(19,342.0) \\
-6,747.4 * * *\end{array}$ & $\begin{array}{c}(138,857.4) \\
-10,822.3\end{array}$ & $\begin{array}{l}(3,368.4) \\
-914.1 * *\end{array}$ & $\begin{array}{c}(26,035.3) \\
-2,259.1\end{array}$ \\
\hline Constant & $\begin{array}{c}(1,072.3) \\
156,186.1 * * * \\
(51,818.9)\end{array}$ & $\begin{array}{c}(4,743.7) \\
642,261.9 * * * \\
(214,205.4)\end{array}$ & $\begin{array}{c}(162.6) \\
22,389.3 * * * \\
(7,857.8)\end{array}$ & $\begin{array}{c}(494.5) \\
25,681.4 \\
(22,328.7)\end{array}$ & $\begin{array}{c}(2,185.9) \\
255,652.7^{* *} \\
(105,633.6)\end{array}$ & $\begin{array}{c}(9,344.4) \\
487,199.8 \\
(421,951.1)\end{array}$ & $\begin{array}{c}(380.7) \\
59,948.1 * * * \\
(18,396.2)\end{array}$ & $\begin{array}{c}(1,752.0) \\
242,518.6^{* * *} \\
(79,114.5)\end{array}$ \\
\hline Observations & 28 & 16 & 28 & 16 & 28 & 16 & 28 & 16 \\
\hline $\begin{array}{l}\text { Number of } \\
\text { bank ID }\end{array}$ & 4 & 4 & 4 & 4 & 4 & 4 & 4 & 4 \\
\hline
\end{tabular}

Standard errors in parentheses

$* * * \mathrm{p}<0.01, * * \mathrm{p}<0.05, * \mathrm{p}<0.1$

Source: Authors' calculation 
Like in tables 2 and 3, table 4 shows that interest rate variables are mostly insignificant in altering the loan variables. Investment interest rate is shockingly insignificant in changing construction loans and transport loans in both periods (specifications 1, 2, 5 and 6). Meanwhile, construction interest rates are significant in all specifications but specification 6 (transportation loan in the second period).

Table 4. The Loan Models for Construction, Trade, Transport, and Finance

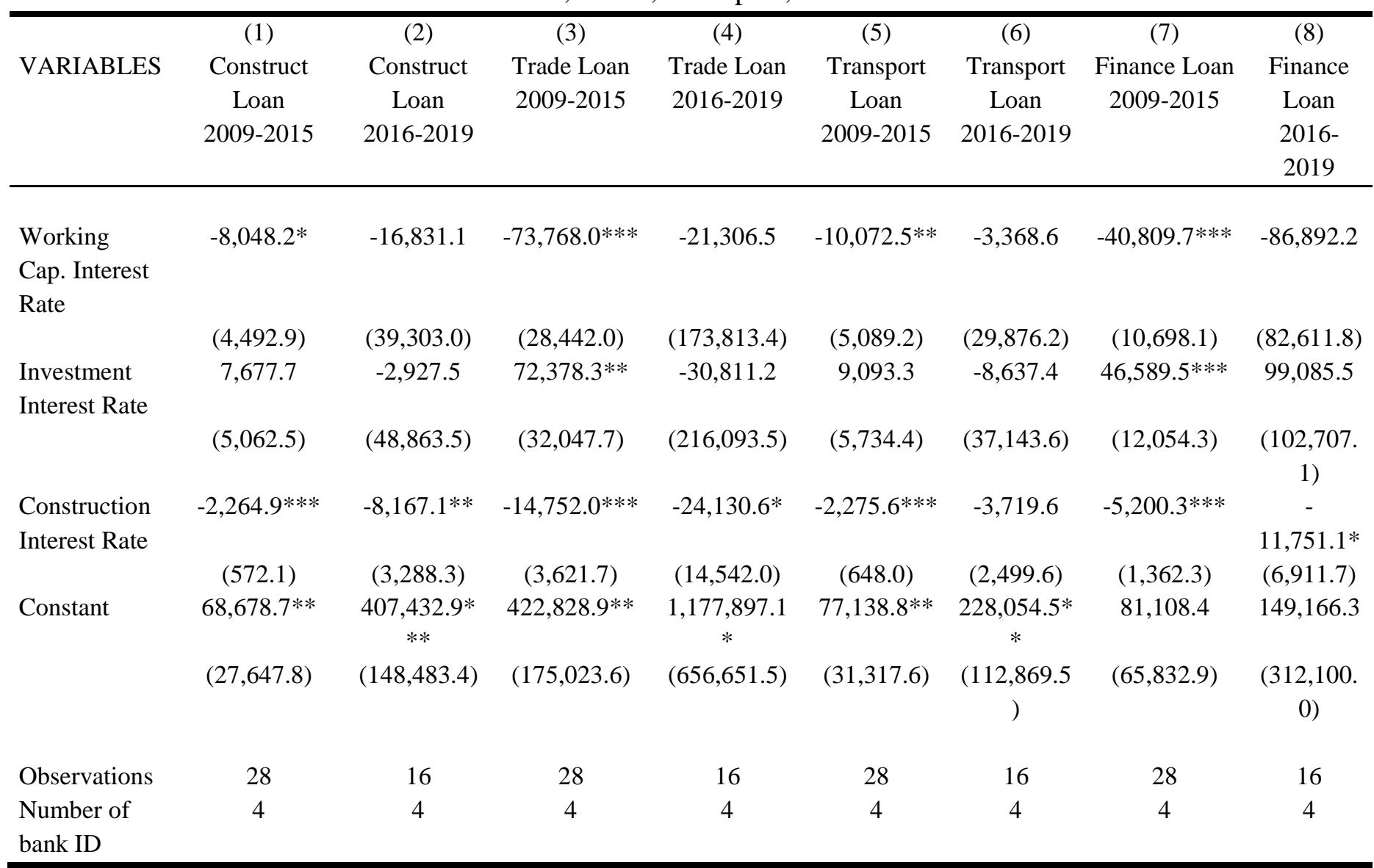

Standard errors in parentheses

$* * * \mathrm{p}<0.01, * * \mathrm{p}<0.05, * \mathrm{p}<0.1$

Source: Authors' calculation

The results presented in tables 2 through 4 show similar patterns, particularly, the effect of interest rate on loan is statistically significant in the pre-Fintech period while the effect is partially significant in the post-Fintech period.

\section{Discussion, Conclusion and Policy Implications}

The presence of Fintech has evolved from time to time and the importance is growing rapidly. The implications of Fintech have affected many groups of people across industry, both buyers and sellers in the market. Some groups benefit from Fintech, while it may harm some other groups.
Banking industry in Indonesia is one that significantly experiences the impact of Fintech. In banking industry, this study has found that the power of interest rate in determining the level of lending attenuates in the presence of Fintech and even may become insignificant. The conventional banking cannot keep up with what Fintech requires from banking to have. Features like easy application, easy credit access, and fast-service are what Fintech can offer to create convenience for the borrowers where conventional banks do not meet. Based on the findings, conventional banks need to consider about simplifying the regulations that applicants must meet to access the 
loans. Although banks can sometimes offer better interest rate to compete with Fintech, the findings suggest that higher or lower interest rate is no longer changing the level of lending in this Fintech era. Convenience is what borrowers expect to have. As literature suggest, Fintech has been able to meet what are underserved or unserved by the banks. The market of underserved or unserved is big which becomes attractive for Fintech to grow. Usually, the underserved market is the market that demands little loan from the banks and the unserved market is the market that does not meet the collateral requirement of the banks. Therefore, it is recommended that the banks reform the requirements to get the loans, particularly for the borrowers who want little loan. However, reforms need to be done by the banks are not as easy as the reforms made by Fintech because of the strict regulations that the government has. Therefore, Indonesian government is highly recommended to reform the regulations to keep up with the changes due to the presence of Fintech. Additionally, banks also need to improve the services to respond to what Fintech can offer.

\section{References}

[1] S Fichman, R.G., Dos Santos, B. L. and Zheng, Z. E.: Digital Innovation as a Fundamental and Powerful Concept in the Information Systems Curriculum, Management Information Systems, Q 38(2): pp. 329-343 (2014)

[2] Economist.: The FinTech Revolution: A wave of startups is changing finance for the better (2015)

[3] Lee, I and Shin, Y. J.: Fintech.: Ecosystem, business models, investment decisions, and challenges. Business Horizons vol. 61, pp. 35-46 (2018)

[4] Buchak, G., Matvos, G., Piskorski, T., and Seru, A.: Fintech, regulatory arbitrage, and the rise of shadow banks. Journal of Financial Economics 130, pp. 453483 (2018)
[5] Jagtiani, J. and John, K.: Fintech: The Impact on Consumers and Regulatory Responses. Journal of Economics and Business. Volume 100, NovemberDecember (2018)

[6] Hill, J.: Financial Institutions in FinTech and the Remaking of Financial Institutions, Academic Press, pp. 69-94 (2018)

[7] Casanova, L., Cornelius, K., and Dutta, S.: Banks, Credit Constraints, and the Financial Technology's Evolving Role in Financing Entrepreneurship and Innovation in Emerging Markets. Academic Press, pp. 161 - 185 (2018)

[8] Chavis, L.W., Klapper, L., and Love, I.: International differences in entrepreneurial finance. In: Cumming, D. (Ed.), The Oxford Handbook of Entrepreneurial Finance. Oxford University Press, Oxford and New York, pp. 755-776 (2012)

[9] Jagtiani, J. and Lemieux, C.: Do Fintech Lenders Penetrate Areas That Are Underserved by Traditional Banks? Journal of Economics and Business, vol. 100, pp. 43 -54 (2018)

[10] Nakashima, T.: Creating credit by making use of mobility with FinTech and IoT, IATSS Research (2018)

[11] Hill, J.: Bank Lending in FinTech and the Remaking of Financial Institutions, Academic Press, pp. 139-156 (2018) 